Александар М. Новаковић

Универзитет у Нишу

Филозофски факултет

Докторске студије филологије

aleksandar.novakovic@ filfak.ni.ac.rs
Оригинални научни рад

УДК: 378(497.11)"2020"

УДК: $37.018 .43-057.87$

УДК: 616-036.21 2019-nCOV

DOI: $10.19090 / \mathrm{mv} .2020 .11 .13-28$

Снежана В. Божић

Универзитет у Нишу

Филозофски факултет

Департман за србистику

snezana.bozic@filfak.ni.ac.rs

\title{
СТАВОВИ СТУДЕНАТА СРБИСТИКЕ ПРЕМА ПЛАТФОРМАМА ЗА ЕЛЕКТРОНСКО УЧЕЫЕ (GOOGLE CLASSROOM И HANGOUTS MEET)
}

АПСТРАКТ: Пандемија вируса 2019-nCOV током марта 2020. године захтевала је од наставника и сарадника на високошколским установама у Републици Србији премештање наставе из факултетских клупа у виртуелне учионице. Филозофски факултет у Нишу је, захваљујући Гугловом софтверском пакету за образовање, односно платформама за електронско учење - Google Classroom и Hangouts Meet, свој рад реорганизовао за свега један дан. У посебном положају нашле су се студије Србистике које, услед специфичне природе језичких и књижевних предмета, захтевају посебан ниво интеракције између наставника и студената. Стога је предмет овога рада испитивање ставова студената Србистике према платформама за електронско учење. Аутори су коришћењем методе теоријске анализе, технике анкетирања и специјално дизајнираног упитника показали да су студенти изузетно задовољни функционалношћу анализираних платформи, уз јасно указивање на њихове добре и лоше стране.

Кључне речи: Google Classroom, Hangouts Meet, платформе за електронско учење, онлајн учење, ИКТ у настави, Филозофски факултет Ниш.

\section{ATTITUDES OF SERBIAN STUDENTS TOWARDS ELECTRONIC LEARNING PLATFORMS (GOOGLE CLASSROOM AND HANGOUTS} MEET)

ABSTRACT: The March 2020 pandemic of the 2019-nCOV virus required teachers and associates at higher education institutions in the Republic of Serbia to move from university classrooms to virtual classrooms. The Faculty of Philosophy in Niš reorganized its work in just one day thanks to the G Suite for education - Google Classroom and Hangouts Meet. Serbian Studies were in a special position because, due to the specific nature of language and literary subjects, they required a particular level of interaction between teachers and students. Therefore, the subject of this paper is examining the attitudes of Serbian students towards e-learning platforms. Using a method of theoretical analysis, a survey technique 
and a specially designed questionnaire, the authors showed that students are extremely satisfied with the functionality of the analyzed platforms, clearly pointing out their good and bad sides.

Key words: Google Classroom, Hangouts Meet, eLearning Platforms, ICT in Teaching, Faculty of Philosophy Niš.

\section{1. УВОД}

Учење на даљину уз помоћ платформи за електронско учење ${ }^{1}$ у условима убрзаног развоја савремених информационо-комуникационих технологија полако постаје део свакодневице великог броја наставника и ученика. Данас постоји на десетине платформи које обезбеђују сарадњу између наставника и ученика, омогућавајући дељење садржаја, испитивање, демонстрирање, као и креирање виртуелних учионица. Другим речима, захваљујући коришћењу платформи за електронско учење тежиште наставе се из школских и факултетских учионица преноси у виртуелни простор. ${ }^{2}$

${ }^{1}$ Електронско учење дефинише се, у најширем смислу, као свако учење подржано употребом рачунара и интернета. Оно има различите видове, у зависности од степена заступљености технологије у реализацији наставног процеса, па се најчешће говори о три варијанте електронског учења: а) традиционална настава у учионици која се одвија уз повремено присуство технологије (употреба презентација, видео-бима, образовни материјали на ЦД-у и сл.); б) виши ниво, тзв. хибридна настава, у којој се један део активности одвија у класичној учионици, а један на мрежи; в) онлајн настава, која се, како само име каже, у потпуности одвија на интернету. Теоретичари електронског учења скрећу пажњу на разлику у значењу појмова учење на даљину и електронско учење, који се, понекад (погрешно) поистовећују. Наиме, појам и пракса учења на даљину временски гледано нису нови (настанак се везује за почетак 19. века); учење на даљину је свако учење у коме су учитељ и ученици физички одвојени и размењују наставне садржаје уз помоћ технологије актуелне за време у коме се учење одвија (дописно школовање, радио, телевизија, аудио- и видео-траке и сл.). Интернет данас успешно замењује све претходне технолошке варијанте и представља главно средство за комуникацију и размену образовних материјала у процесу учења на даљину. Дакле, само трећи вид електронског учења - онлајн настава јесте учење на даљину. Видети о томе: Шћепановић 2010.

2 Промене о којима је реч условљавају појмовно, терминолошко и садржинско богаћење научних дисциплина које се баве наставом. Тако се у оквирима савремене методике наставе афирмисао појам виртуелне колаборације, сарадње на мрежи. Развој интернета у правцу знатно веће интерактивности у којој су „корисници 
Пракса показује да ученици и студенти са нескривеним симпатијама прихватају овај нови вид наставе и врло брзо и лако му се прилагођавају. Велики број алата које електронске платформе пружају својим корисницима (како наставницима тако и ученицима) обезбеђују очигледност у настави, појачану интерактивност и пријатну атмосферу за учење.

Компанија „Гугл” је убрзо по почетку увођења интернета у домове препознала његов будући значај у образовању. Зато је још 2006. године објавила постојање низа својих апликација за учење на даљину, тада познатих под именом Google Apps for Education. Временом се овај софтверски пакет мењао, развијао и усавршавао, тако да је првобитну поменуту верзију заменио $G$ Suite for Education, којим се данас служе милиони корисника, укључујући и образовне институције широм света. Реч је о већем броју алата и платформи, које омогућавају учење кроз стварање виртуелних учионица. Захваљујући својим могућностима, две платформе у оквиру овог софтверског пакета посебно су наишле на прихватање од стране наставника и ученика/студената - Google Classroom (срп. Гугл учионица) и Hangouts Meet. Првопоменута зато што пружа могућност организованог дељења наставних материјала са ученицима и писану кореспонденцију, а друга због могућности успостављања видео-конференције, односно учионичких услова у виртуелном окружењу. Притом, свим заинтересованим наставницима компанија „Гугл” обезбедила је бесплатна видео-упутства и онлајн курсеве ${ }^{3}$ за коришћење поменутих платформи.

У новом окружењу и настава на универзитетима се мења и прилагођава захтевима времена и технолошким иновацијама. Факултети под повољним условима од компаније „Гугл” добијају поменути софтверски пакет за образовање, због чега је све више факултетских наставника и

истовремено и учесници у стварању садржаја” и афирмација принципа „учешћа, сарадње и доприноса, при чему је друштвена страна технологије од изузетног значаја” (Радић Бојанић 2012: 5), омогућио је да говоримо о виртуелној колаборацији као његовом важном образовном потенцијалу. Актери колаборације (наставници и ученици/студенти) деле и /или заједнички креирају наставне ресурсе и материјале, стичући истовремено нова знања. У сарадњи која се одвија на мрежи од пресудног значаја је комуникација, а њена примарна интенција је „промовисање образовних циљева кроз развој знања студената, као и побољшање квалитета учења из преспективе студената" (Радић Бојанић 2012: 25, 26). Више о овоме: Божић 2018.

${ }^{3}$ Видео-упутства и онлајн курсеви доступни су на званичној веб-страници компаније „Гугл”: https://teachercenter.withgoogle.com. 
сарадника који се одлучују да свој наставни рад осавремене коришћењем платформи за електронско учење. Позитиван пример овог начина модернизације универзитетске наставе приметан је на Филозофском факултету у Нишу, на коме се већ две године активно користи. Међу првима су се са могућностима две поменуте платформе сусрели студенти Србистике на предавањима и вежбама из предмета Интернет и мултимедија у настави српског језика и књижевности. Но, друштвене прилике у марту 2020. године утицале су да студенти Србистике заједно са својим наставницима и сарадницима у потпуности пређу на овај вид учења. Зато је предмет овога рада испитивање ставова студената Србистике према Гугловим платформама за електронско учење.

Рад је подељен на шест поглавља. Након уводних напомена, дат је преглед претходних истраживања у вези са корисношћу платформи за електронско учење. У трећем поглављу изнете су основне методолошке поставке, док се у четвртом поглављу анализирају добијени резултати. Пето поглавље доноси најважније закључке, а шесто попис коришћене литературе.

\section{2. ПРЕТХОДНА ИСТРАЖИВАЮА}

Пракса показује да технологија утиче на промену начина реализације наставе. Савремена информационо-комуникациона средства пружају могућност наставницима и ученицима/студентима да путем виртуелних учионица, какве су Google Classroom и Hangouts Meet, испуњавају своје наставне циљеве. У протеклих пет година написан је већи број радова о корисности Гугловог софтверског пакета у образовању. Аутори, махом са англоамеричког подручја, посебну пажњу усмерили су на испитивање функционалности поменутих платформи, као најпознатијих и најприступачнијих платформи за електронско учење.

Гугл учионица представља платформу која омогућава сарадњу између наставника и ученика кроз дељење текстуалних, видео- и аудио-материјала, односно успостављање директне комуникације путем текстуалних порука (Шаране и сар. 2016; Бат и сар. 2018; Бармен, Картикејан 2019; Рамадани и cap. 2019). Ифтахар (2016) наглашава да се са њеном појавом 2014. године променио и начин на који се виртуелне учионице користе у настави. Јанзен (2014) као позитивне стране Гугл учионище истиче: једноставност у коришћењу, уштеду времена у припреми часа, прилагодљивост различитим приступима у организацији наставе, могућност коришћења на мобилним телефонима, као и то што не захтева финансијске издатке за наставнике (и 
образовне институције). Еспиноза и сар. (2017) истичу да Гугл учионица представља прави пример виртуелног учења на даљину. На узорку од 100 испитаника резултати су показали да, захваљујући својој једноставности, обезбеђује добру интеракцију између учесника у наставном процесу, те због тога наилази на прихватање од стране студената. Задовољство због коришћења у настави, поред студената, исказују и наставници. Каил (2014) показује да су наставници на универзитетима позитивно настројени ка њеној имплементацији у свакодневне академске активности. Бексети и сар. (2018) сматрају да коришћење ове платформе мотивишуће делује на студенте, што се уочава кроз повећање броја оних који активно учествују у настави. Међутим, има и оних, додуше ретких, који сматрају да Гугл учионища није уопште једноставна за употребу. Азхар и Икбал (2018) су, анализирајући одговоре 12 наставника који су најмање један семестар користили Гугл учионииу, дошли до сазнања да је наставници виде само као додатно наставно средство, без посебног утицаја на побољшање резултата. Посебне замерке упутили су на непостојање кориснику прилагођеног окружења (енг. userfriendly interface), због чега ова платформа може бити тешка за коришћење.

До сличних резултата, само у вези са коришћењем платформе Hangouts Meet долази Кобајаши (2015). Резултати спроведеног истраживања показују да је у питању корисно наставно средство, али не баш тако једноставно за коришћење. Но, Чен и сар. (2015) истичу као највеће предости коришћења ове платформе могућности успостављања видео-позива, дељења екрана и текстуалног разговора, захваљујући којима се постиже интерактивност у настави. Форсит (2016) сматра да је видео-конференција кључно наставно средство за обезбеђивање професионалног развоја студената. У вези са тим, Левандовски (2015) демонстрира значај ове платформе у развоју језичких компетенција приликом учења језика на даљину, а Хазвани и сар. (2017) запажају да је највећи број ученика изузетно задовољан њеном функционалношћу у настави.

С обзиром на то да је развој платформи за електронско учење још увек у повоју, примећује се да долази до честог мешања појмова наставно средство и платформа. Тако разни аутори платформе за електронско учење често називају и модерним наставним средствима. Међутим, ваљало би водити рачуна о терминима који ће се користити. Под платформама треба подразумевати виртуелни простор који омогућава успостављање интеракције између наставника и ученика/студената, чија функционалност зависи од алата (у овом случају, виртуелних наставних средстава) којима је тај простор опремљен. Другим речима, ако је у традиционалној учионици пројектор 
представљао наставно средство за постизање принципа очигледности, онда ће аудио- или видео-позив бити само алат у учионицама какве су Google Classroom и Hangouts Meet.

\section{3. МЕТОДОЛОШКЕ ПОСТАВКЕ ИСТРАЖИВАҢА}

\section{1. Предмет и иүиљ истраживања}

Пандемија вируса 2019-nCOV почетком марта 2020. године утицала је на доношење директних мера државног врха Републике Србије којима су привремено затворене предшколске установе, школе и факултети. Новонастала ситуација захтевала је брзе реакције директора и декана да наставу реогранизују и омогуће запосленима и ученицима/студентима рад од куће. Филозофски факултет у Нишу је за само један дан (од проглашења ванредне ситуације) у потпуности омогућио наставницима и сарадницима да изводе наставу, а студентима да је похађају. ${ }^{4}$ Захваљујући електронским платформама (Google Classroom и Hangouts Meet) није изгубљен ниједан час, нити се регуларност академске године довела у питање. Иако су студенти Србистике у оквиру предмета на основним академским студијама имали прилику да се сусретну са овим и сличним платформама за учење, промена са класичног начина извођења наставе на наставу путем савремених информационо-комуникационих технологија била је ненадана и брза. Зато је предмет овог рада, као што смо већ истакли, испитивање ставова студената Србистике према платформама за електронско учење (Google Classroom и Hangouts Meet), са циљем провере њихове функционалности у реалним условима учења на даљину.

\footnotetext{
4 Ова чињеница потврђује да је Филозофски факултет као образовна институција достигао задовољавајући ниво електронске зрелости. Наиме, темпо интеграције технологије у образовним установама је различит и резултати се, на ширем плану (који укључују рад и активности наставника, сарадника, ученика, студената...), могу сагледавати „тек када свака образовна установа достигне одређен ниво електронске зрелости. Према дефиницији коју је дала Британска агенщија за образовну комуникацију u технологију, електронска зрелост образовне институције се процењује на основу тога колико нека организација на стратешки и ефикасан начин користи информационо-комуникационе технологије да унапреди образовна постигнућа" (Шћепановић 2010: 24).
} 


\section{2. Истраживачки задации}

У складу са постављеним предметом и циљем истраживања дефинисани су следећи истраживачки задаци:

1. Анализирати ставове студената према коришћеним платформама за електронско учење (Google Classroom и Hangouts Meet).

2. У Уврдити којој од поменутих платформи су студенти наклоњенији.

3. Испитати мишљење студената о томе да ли су платформе за електронско учење погодније за реализацију предавања или извођење вежби.

4. Испитати мишљење студената о томе да ли су платформе за електронско учење погодније за часове језичких предмета или часове књижевних предмета.

\section{3. Хипотезе истраживања}

На основу постављених истраживачких задатака, аутори су поставили следеће хипотезе:

1. Претпоставља се да ће студенти бити задовољни платформама за електронско учење у новонасталим околностима.

2. Претпоставља се да ће студенти бити наклоњенији платформи Hangouts Meet која омогућава успостављање видео-конференције.

3. Претпоставља се да студенти сматрају да су платформе за електронско учење погодније за реализацију часова предавања.

4. Претпоставља се да неће бити посебне разлике у мишљењу студената о томе да ли су платформе погодније за часове језичких или књижевних предмета.

\section{4. Узорак, методе, технике и инструменти}

Истраживање ставова студената према платформама за електронско учење је спроведено средином марта 2020. године. У истраживању је учествовало укупно 64 студента студија Србистике, и то 59 студенткиња и 5 студената, односно 15 студената прве године, 16 студената друге године, 15 студената треће године и 18 студената четврте године. У истраживању је коришћена метода теоријске анализе, односно техника анкетирања ${ }^{5}$. Ради реализације истраживања за потребе овог рада коришћен је специјално

\footnotetext{
${ }^{5}$ Упитник доступан на адреси: shorturl.at/jkr04.
} 
дизајниран онлајн упитник - Упитник у вези са ставовима студената према платформама за електронско учење (скр. УССППЗУ). Студенти су износили своје ставове у вези са платформама за електронско учење дајући одговоре на укупно 30 питања, од којих је 14 питања затвореног типа, односно 16 питања отвореног типа.

\section{4. АНАЛИЗА РЕЗУЛТАТА}

Иако је прелаз са традиционалног начина извођења наставе на извођење наставе путем савремених информационо-комуникационих технологија био неочекиван и веома брз, и стога недовољно припремљен, анализа резултата истраживања показала је да су платформе Google Classroom и Hangouts Meet у потпуности (36 испитаника) или делимично (20 испитаника) испуниле очекивања студената или чак и изненадиле својим могућностима. Према речима испитаника, захваљујући овим платформама „безболно се прешло на нови начин учења", који већ сада показује своје потенцијале. Међутим, испитаници су такође приметили да је основна разлика између часова који се одржавају у традиционалној учионици и оних који се реализују у виртуелној у томе што се у другопоменутој комуникација делимично осиромашује, а концентрација (временски гледано) скраћује. Ипак, чак педесет и петоро студената (86\%) је задовољно или делимично задовољно интеракцијом коју су успоставили са наставницима уз помоћ двеју платформи.

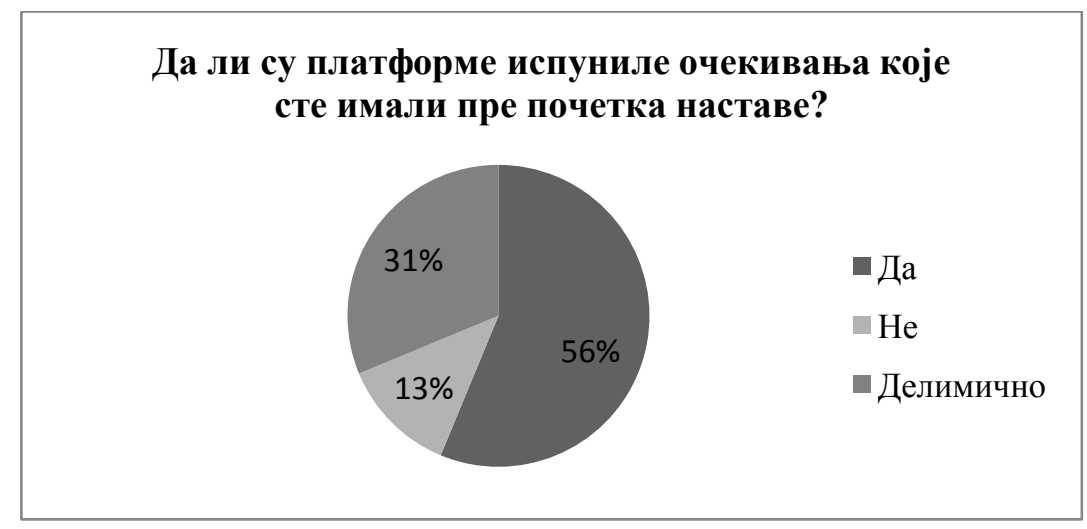

Графички приказ 1. Графички приказ испуњености очекивања које су студенти имали од платформи за електронско учење

Студенти су врло лепо запазили да се ове две платформе по својој природи разликују једна од друге. Док је Гугл учионица првенствено намењена 
дељењу материјала, Hangouts Meet је платформа која обезбеђује школски рад у виртуелном окружењу. Зато су студенти мишљења да је ове две платформе најбоље користити истовремено, како би се предности и недостаци сваке од њих компензовали. Ипак, уколико би, под хипотетичким условима, морали да се одлуче за једну од две платформе, четрдесет и четворо студената (69\%) би изабрало Google Hangouts, а двадесеторо (31\%) Гугл учионииу. Као предности Hangouts Meet-a студенти су истакли коришћење видео-наставе 6 , успостављање директног контакта, добијање подробних објашњења од наставника путем живе речи, једноставност корисничког интерфејса, појачану интерактивност и могућност коришћења презентација у настави. Са друге стране, они испитаници који би се одлучили за коришћење само Гугл учионище, то би учинили због прегледности коју она нуди студентима - „сви материјали су уредно поређани према темама о којима се на часовима разговара”, једноставности у коришћењу и аутоматским обавештењима о новопристиглим материјалима. На основу одговора се, такође, може закључити да овај вид извођења наставе више одговара интровертним ученицима, који воле да „сами и у миру уче”, односно онима којима је „досадно слушати професоре преко Hangout Meet-a".

Са друге стране, студенти су посебно апострофирали разлике које постоје између традиционалног начина извођења наставе и онлајн учења, због чега су и даље наклоњени првом виду њене реализације. Наиме, студенти су мишљења да у „класичној учионици” имају више могућности да размене мишљење са својим наставницима и да кроз такву интеракцију брже и једноставније дођу до одговора на одређена питања и недоумице у вези са градивом. Виртуелна учионица им ствара осећај нелагодности због специфичних услова извођења часова - непостојање табле и социјалне сарадње, великог броја информација које се не могу брзо обрадити и често монотони (и досадни) часови, односно због постојања страха да ће услед прекида интернета бити онемогућени да присуствују часовима.

Студенти који користе Гугл учионииу немају посебних замерки у вези са њеном функционалношћу, осим што примећују да од својих наставника и сарадника добијају „материјале које иначе не би користили”. Нешто више замерки испитаници су упутили на рачун друге платформе (Hangout Meet): споро добијање повратне информације, појава микрофоније и шумова, честа

\footnotetext{
${ }^{6}$ Четрдесет и шесторо студената (72\%) на својим часовима редовно укључује камеру, док свега осамнаесторо (28\%) то никада не чини.
} 
кочења везе, звук лошег квалитета, прекид часа приликом ,уласка нових учесника" на час и често укључивање у разговор у истом тренутку због чега се губи драгоцено време. Уз то, тридесет и троје студената (52\%) је навело да понекад има техничке проблеме који су се манифестовали кроз немогућност присуствовања часу, прекид мреже или појаву буке у позадини.

Студенти су закључили да је платформа Hangouts Meet, због интеракције коју обезбеђује, далеко погоднија за извођење наставе језичких, односно књижевних предмета у поређењу са платформом Google Classroom. Такође, највећи број студената је наведену платформу окарактерисао као кориснију за извођење и часова предавања и часова вежби због успостављања директног аудио-визуелног контакта (в. Графички приказ 2). Притом, већина студената није до сада користила ниједну другу платформу у настави, изузев друштвених мрежа и апликација (Фејсбук, Вајбер). Неколицина студената навела је да су им познате платформе PBworks, односно Zoom, за које су констатовали да „не могу прићи Гугловим платформама”. Само троје студената (5\%) би се радије одлучило за употребу Фејсбука у настави.

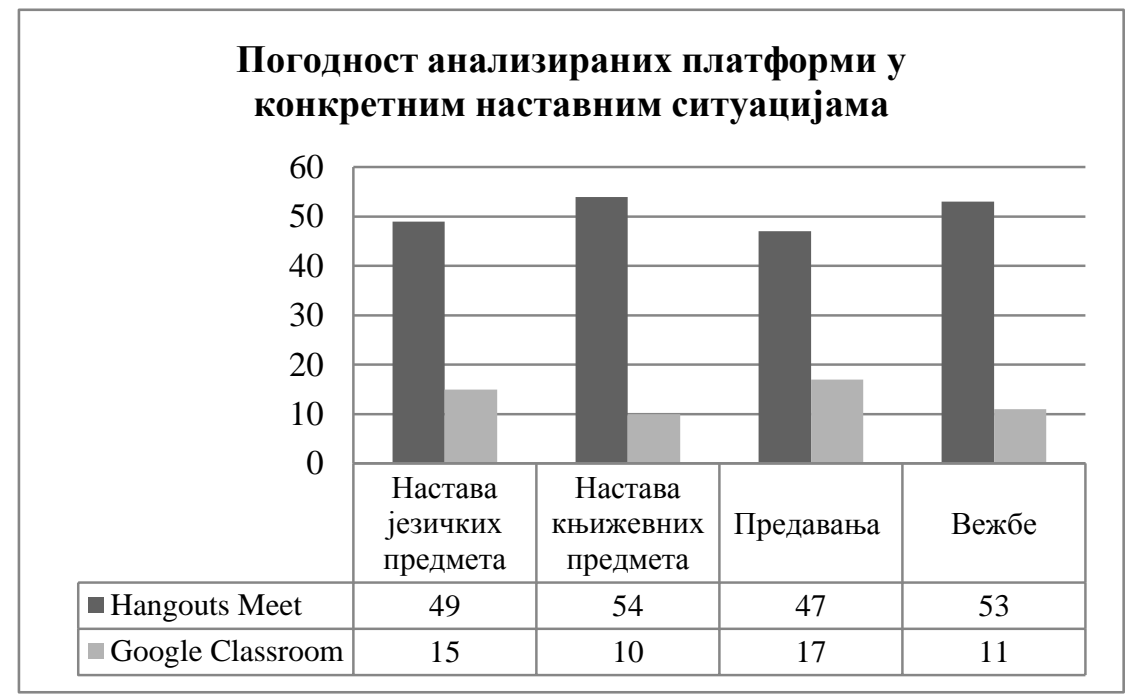

Графички приказ 2. Мишљење студената о погодности платформи у конкретним наставним ситуацијама 


\section{1. Дискусија}

Спроведено истраживање показало је да платформе за електронско учење у великој мери наилазе на прихватање од стране студената. Податак да се чак четрдесет и један испитаник (64\%) сагласио да би волео да настави са коришћењем платформи за електронско учење и након повратка у факултетске клупе говори у прилог чињеници да су анализиране платформе оставиле позитиван утисак. Наиме, у условима када се читав наставни процес одвија уз помоћ двеју платформи, показује се значај савремених информационо-комуникационих технологија у настави и на савременом универзитету.

Захваљујући платформама Google Classroom и Hangout Meet настава на Филозофском факултету у Нишу је „преко ноћи” транспонована из класичне (,„неелектронске”) учионице у виртуелну, без последица по квалитет наставе, о чему сведоче позитивни одговори анкетираних студената. Захваљујући коришћењу обе платформе истовремено, наставници и сарадници на Филозофском факултету у Нишу надоместили су очигледне недостатке сваке од њих (в. Табела 1).

\begin{tabular}{|c|c|c|c|}
\hline \multicolumn{2}{|c|}{ GOOGLE CLASSROOM } & \multicolumn{2}{|c|}{ HANGOUTS MEET } \\
\hline Предности & Недостаци & Предности & Недостаци \\
\hline $\begin{array}{c}\text { Једноставност } \\
\text { приликом } \\
\text { коришћења } \\
\end{array}$ & $\begin{array}{l}\text { Непостојање } \\
\text { видео-позива }\end{array}$ & $\begin{array}{c}\text { Једноставност } \\
\text { приликом } \\
\text { коришћења } \\
\end{array}$ & $\begin{array}{c}\text { Појава } \\
\text { микрофоније }\end{array}$ \\
\hline Прегледност & $\begin{array}{c}\text { Смањена } \\
\text { интерактивност } \\
\text { између професора } \\
\text { и студената } \\
\end{array}$ & $\begin{array}{l}\text { Успостављање } \\
\text { видео-позива }\end{array}$ & Појава шумова \\
\hline $\begin{array}{c}\text { Могућност дељења } \\
\text { материјала }\end{array}$ & & $\begin{array}{c}\text { Повећана } \\
\text { интеракција }\end{array}$ & $\begin{array}{c}\text { Укључивање } \\
\text { више говорника у } \\
\text { истом тренутку } \\
\end{array}$ \\
\hline Текстуални разговор & & $\begin{array}{c}\text { Могућност } \\
\text { дељења екрана }\end{array}$ & $\begin{array}{c}\text { Немогућност } \\
\text { предавача који } \\
\text { дели свој екран да } \\
\text { види поруке. } \\
\end{array}$ \\
\hline $\begin{array}{c}\text { Аутоматска } \\
\text { обавештења о } \\
\text { новопостављеним } \\
\text { материјалима }\end{array}$ & & $\begin{array}{c}\text { Текстуални } \\
\text { разговор }\end{array}$ & \\
\hline
\end{tabular}

Табела 1. Предности и недостаци анализираних платформи 
Анкетирани студенти Србистике су, ипак, исказали своју наклоност према платформи Hangouts Meet, јер обезбеђује директни аудио-визуелни контакт са предавачем, док то није случај са платформом Google Classroom која, уз дељење наставних материјала, обезбеђује само разговор уз помоћ текстуалних порука. Иако се претпостављало да ће платформа Hangouts Meet бити погоднија за реализацију часова предавања, спретност сарадника и дисциплинованост студената утицале су да испитаници буду изузетно задовољни начином реализације часова вежби. Без посебне разлике између наставе језичких и књижевних предмета, студенти су Hangouts Meet препознали као погоднију платформу за њихову реализацију. Из тог произилази закључак да свеопшти позитивни став према платформама за електронско учење потиче како од могућности које пружају тако и од спретности наставника, сарадника и студената који их користе.

\section{5. ЗАКљУЧАК}

Друштвене прилике у свету током марта 2020. године утицале су да се факултетске клупе замене виртуелним учионицама. Ванредне околности захтевале су брзу реакцију наставника и сарадника свих високошколских установа у Републици Србији како би академску годину успешно привели крају. Захваљујући платформама за електронско учење - Google Classroom и Hangouts Meet на Филозофском факултету у Нишу, прелазак на другачији начин извођења наставе од уобичајеног - на учење на даљину, односно онлајн учење био је веома брз и ефикасан, због чега студенти нису изгубили ни један једини час.

Јединствена прилика да се читав рад наставника, сарадника и студената реализује само у условима виртуелних учионица, показала је њихову моћ и, бар на кратко, нас увела у учионице какве ће бити у блиској будућности. Специфична структура студијског програма Србистике поставља, и у нормалним условима, посебне захтеве за реализацију наставе језичких и књижевних предмета који захтевају директну интеракцију између наставника и студената. Стога су новонастале околности представљале посебан изазов за реализацију наставе на овом студијском програму. Одговори студената све четири године Србистике показали су да су студенти изузетно задовољни функционалношћу анализираних платформи за учење на даљину, који свој пуни потенцијал остварују међусобним допуњавањем. Наиме, поред низа позитивних особина (интерактивност, једноставност, текстуални, видео- и аудио-позиви, текстуална комуникација), платформе 
имају и своје недостатке (микрофонија, застајкивања, појава шумова, итд.), који се могу надоместити њиховом наизменичном употребом у наставном процесу. Такође, позитиван став према платформама за учење, студенти су формирали и захваљујући спретности и брзини којом су наставници и сарадници на Департману за србистику овладали овим платформама и начину на који их користе на својим часовима, односно због задовољавајућег нивоа њихових дигиталних компетенција ${ }^{7}$. Ипак, студенти су наклоњенији платформи Hangouts Meet која омогућава директни аудио-визуелни контакт са предавачима и која је подједнако ефикасна и на часовима предавања и на часовима вежби.

На основу свега представљеног може се закључити да је реч о функционалним платформама за учење на даљину. Захваљујући сложеним алгоритмима које користе, платформе Google Classroom и Hangouts Meet представљају виртуелне учионице будућности, које ће несумњиво то и постати уколико се отклоне одређени њихови недостаци и када се створе технички услови да се то и догоди.

77 Дигитална компетенција наставника зависи од нивоа његове дигиталне писмености и представља једну од осам кључних компетенција за целоживотно образовање Европске уније. У службеном листу ове организације дигитална компетенција дефинише се као „самоуверено и промишљено коришћење технологија информационог друштва за рад, слободно време и комуницирање. Дигитална компетенција се базира на основним ИКТ вештинама, а то су примена рачунара за тражење, процењивање, складиштење, производњу, презентовање и размену информација, као и за учешће, комуникацију и сарадњу путем интернета" (према: Смернице за унапређивање улоге информационо-комуникационих технологија у образовању, 41). Министарство просвете, науке и технолошког развоја РС први пут је 2017. године објавило документ Оквир дигиталних компетенција - Наставник за дигитално доба, којим су одређене „вештине, циљеви и очекивани исходи који чине корпус дигиталних компетенција нставничке професије" (Више о овоме у: Божић 2018: 26, 27). Ажурирани документ (2019) доступан је на сајту Завода за унапређивање васпитања и образовања: https://zuov.gov.rs/usvojen-novi-okvirdigitalnih-kompetencija-nastavnika/ [7. 4. 2020]. 


\section{ЛИТЕРАТУРА}

Abazi-Bexheti, L., Kadriu, A., Apostolova-Trpkovska, M., Jajaga, E., Abazi-Alili, H. (2018). LMS Solution: Evidence of Google Classroom Usage in Higher Education, Business Systems Research Journal 9 (1): 31-43.

Azhar, A. K., Iqbal, N. (2018). Effectiveness of Google Classroom: Teachers' perceptions. Prizren Social Science Journal 2: 52-66.

Barman, B., Karthikeyan, J. (2019). Facilitating ELT through Moodle and Google Classroom. Restaurant Business 118 (10): 506-518.

Божић, C. (2018). Пријатељство на мрежи - о интернету и настави къижевности. Ниш: Филозофски факултет [Воžić, S. (2018). Prijateljstvo na mreži - o internetu i nastavi književnosti. Niš: Filozofski fakultet].

Bhat, S., Raju, R., Bikramjit, A., D’Souza, R. (2018). Leveraging E-Learning through Google Classroom: A Usability Study. Journal of Engineering Education Transformations 31 (3): 129-135.

Espinosa, N., Estira, K. L., Ventayen, R. J. M. (2017). Usability Evaluation of Google Classroom: Basis for the Adaptation of $\mathrm{G}$ Suite E-Learning Platform. Asia Pacific Journal of Education, Arts, and Science 5 (1): 4751.

Iftakhar, S. (2016). Google Classroom: what works and how?. Journal of Education and Social Sciences 3: 12-18.

Janzen, M. (2014). Hot Team: Google Classroom. Приступљено 18. 3. 2020. URL: < tlt.psu.edu/2014/12/04/hot-team-google-classroom>.

Kobayashi, M. (2015). Students' Evaluation of Google Hangouts Through A Cross-Cultural Group Discussion Activity. Turkish Online Journal of Distance Education 16 (2): 28-39.

Lewandowski, M. (2015). Creating virtual classrooms (using Google Hangouts) for improving language competency. Language Issues: The ESOL Journal 26 (1): 37-42.

Radić-Bojanić, B. (prir. 2012). Virtuelna interakcija i kolaboracija u nastavi engleskog jezika i književnosti. Novi Sad: Filozofski fakultet.

Ramadhani, R., Umam, R., Abdurrahman, A., Syazali, M. (2019). The Effect of Flipped-Problem Based Learning Model Integrated With LMS-Google Classroom for Senior High School Students. Journal for the Education of Gifted Young Scientists 7 (2): 137-158. 
Смернище за унапређивағе улоге информащионо-комуникационих технологија y образовању (2013). Национални просветни савет Републике Србије. Приступљено 7. 4. 2020. URL:

<http://www.nps.gov.rs/wp-

content/uploads/2013/12/Smernice_sredjeno_cir.pdf $>$ [Smernice za unapređivanje uloge informaciono-komunikacionih tehnologija $\mathrm{u}$ obrazovanju (2013). Nacionalni prosvetni savet Republike Srbije].

Shaharanee, I. N. M., Jamil, J. M., Rodzi, S. S. M. (2016). The Application of Google Classroom as a Tool for Teaching and Learning. Journal of Telecommunication, Electronic and Computer Engineering 8 (10): 5-8.

Forsyth, E. (2016). Using videoconferencing for professional development and meetings. Computers in Libraries 36 (7): 11-14.

Hazwanie, H., Chong, D., Pran Kishore, D., Wong, P. S., Lee, M. S., Maharajan, M. K., Lee, E. L., Baloch, H. Z. (2017). Student's perceptions of live online virtual e-problem based learning (LOVE-PBL) using Google Hangouts. Education in Medicine Journal 9 (4): 31-39.

Cahill, J. L. (2014). University professors' perceptions about the impact of integrating Google applications on students' communication and collaboration skills. Journal of Research Initiatives 1: 7.

Chan, T., Joshi, N., Lin, M., Mehta, N. (2015). Using Google Hangouts on Air for Medical Education: A Disruptive Way to Leverage and Facilitate Remote Communication and Collaboration. Journal of Graduate Medical Education 7 (2): 171-173.

Šćepanović, D. (2010). Elektronsko učenje i obrazovanje na daljinu - odabrane teme. Beograd: D. Šćepanović. 


\author{
Aleksandar M. Novaković \\ University of Niš \\ Faculty of Philosophy \\ Doctoral studies in philology \\ Snežana V. Božić \\ University of Niš \\ Faculty of Philosophy \\ Department of Serbian Studies
}

\title{
ATTITUDES OF SERBIAN STUDENTS TOWARDS ELECTRONIC LEARNING PLATFORMS (GOOGLE CLASSROOM AND HANGOUTS MEET)
}

Summary

The March 2020 pandemic of the 2019-nCOV virus required teachers and associates at higher education institutions in the Republic of Serbia to move from university classrooms to virtual classrooms. The Faculty of Philosophy in Niš reorganized its work in just one day thanks to the G Suite for education - Google Classroom and Hangouts Meet. With the complex algorithms they use, the Google Classroom and Hangouts Meet platforms are virtual classrooms of the future, which will undoubtedly become so if certain deficiencies are eliminated and the technical conditions are created. Serbian Studies were in a special position because, due to the specific nature of language and literary subjects, they required a special level of interaction between teachers and students. Therefore, the subject of this paper is examining the attitudes of Serbian students towards e-learning platforms. Using a method of theoretical analysis, a survey technique and a specially designed questionnaire, the authors showed that students are extremely satisfied with the functionality of the analyzed platforms, clearly pointing out their good and bad sides. In addition to a number of positive features (interactivity, simplicity, text, video and audio calls, text communication), the platforms also have disadvantages (pauses, noise, etc.) that can be replaced by their alternating use in the teaching process. Also, the students have developed a positive attitude towards learning platforms thanks to the skills and speed with which teachers and associates at the Department of Serbian Studies have mastered them and the way they used them in their classes, or because of the satisfactory level of their digital competencies. However, the students are more inclined towards the Hangouts Meet platform, which provides a direct audio-visual contact with the lecturers and is equally effective in both class and exercise classes.

Key words: Google Classroom, Hangouts Meet, eLearning Platforms, ICT in Teaching, Faculty of Philosophy Niš.

Примљено: 11. 4. 2020.

Прихваћено: 20. 6. 2020. 